\title{
PENINGKATAN KEMAMPUAN MAHASISWA MENULIS CERITA ANAK MELALUI STRATEGI MENULIS TERBIMBING
}

\author{
Enny Zubaidah \\ FIP Universitas Negeri Yogyakarta \\ email: enny_zubaidah@yahoo.com
}

\begin{abstract}
Abstrak
Penelitian tindakan ini bertujuan meningkatkan kemampuan mahasiswa menulis cerita anak melalui strategi terbimbing. Subjek penelitian adalah mahasiswa PGSD FIP UNY semester tiga. Pengumpulan data menggunakan tes awal dan tes akhir tiap siklus, wawancara, observasi, catatan lapangan, portofolio, dan angket. Analisis data menggunakan statistik deskriptif. Hasil penelitian sebagai berikut. Pertama, penggunaan strategi menulis terbimbing dapat meningkatan kemampuan mahasiswa menulis cerita anak. Proses pembelajaran yang dilakukan dengan cara memahamkan kepada mahasiswa tentang unsur cerita anak dan unsur kebahasaan melalui: (a) membaca cerita anak karya orang lain, (b) mendiskusikan hasil kegiatan membaca cerita melalui kegiatan menganalisis unsur-unsur cerita, (c) mengisahkan kembali cerita yang telah dibaca, dan (d) menulis cerita secara mandiri. Kedua, kemampuan mahasiswa dalam menulis cerita anak meningkat pada setiap siklus. Hasil tes awal tidak ada mahasiswa $(0 \%)$ yang memiliki tingkat kemampuan tinggi, 7 mahasiswa (25,9\%) sedang, dan 20 mahasiswa $(74,1 \%)$ kurang. Hasil tes akhir siklus ketiga, 12 mahasiswa (44\%) memiliki tingkat kemampuan tinggi, 15 mahasiswa (56\%) sedang, dan tidak ada mahasiswa yang memiliki tingkat kemampuan kurang.
\end{abstract}

Kata kunci: menulis cerita, cerita anak, strategi menulis terbimbing

\section{IMPROVING STUDENTS' SKILLS IN WRITING CHILDREN'S STORIES THROUGH THE GUIDED WRITING STRATEGY}

\begin{abstract}
This action research study aims to improve students' skills in writing children's stories through the guided writing strategy. The research subjects were semester three students of PGSD FIP UNY. The data were collected through a pretest and a posttest in each cycle, interviews, observations, field notes, portfolio, and questionnaires. The data were analyzed using descriptive statistics. The results of the study were as follows. First, the use of the guided writing strategy was capable of improving students' skills in writing children's stories. The learning process was implemented by making the students understand elements of a child's story and language elements through: (a) reading children's stories by other writers, (b) discussing strory reading results by analyzing story elements, (c) retelling the stories that had been read, and (d) writing stories independently. Second, the students' skills in writing children's stories improved in each cycle. Based on the pretest results, no student $(0 \%)$ had a high level of skills, 7 students $(25.9 \%)$ had a moderate level of skills, and 20 students $(74.1 \%)$ had a low level of skills. Based on the posttest results in Cycle 3, 12 students (44\%) had a high level of skills, 15 students (56\%) had a moderate level of skills, and no student had a low level of skills.
\end{abstract}

Keywords: story writing, schildren's stories, guided writing strategy 


\section{PENDAHULUAN}

Menulis adalah suatu kegiatan untuk menyampaikan gagasan, pikiran, dan perasaan dalam bentuk tulisan agar dapat dimengerti oleh pembaca. Untuk itu seorang penulis perlu tahu apa yang akan ditulis, apa tujuan menulis, untuk siapa hasil menulis, dan bagaimana caranya menulis. Terdapat beberapa jenis tulisan yang juga menentukan, siapa pembacanya, salah satu di antaranya adalah tulisan yang berupa cerita anak (Tompkins \& Hoskinson, 1995:19).

Cerita anak (CA) idealnya ditulis oleh anak. Akan tetapi, kemampuan menulis CA pada anak-anak masih kurang. Kurangnya siswa dalam menulis ini antara lain adalah menjadi tanggung jawab guru di sekolah. Untuk itu, guru hendaknya memiliki tanggung jawab agar para siswanya memiliki kemampuan itu. Walaupun para guru tidak dituntut untuk menjadi penulis CA.Untuk mendukung hal itu, calon guru SD-lah yang harus dipersiapkan oleh lembaga penyelenggara PGSD agar dapat melaksanakan pembelajaran tersebut, termasuk mahasiswa PGSD di UNY yang dilakukan secara terbimbing.

Secara konseptual, pembelajaran melalui pembimbingan ini mementingkan dialog atau tanya jawab. Seperti halnya dikatakan Vigotsky (via Berk \& Adam W., 1995:108) bahwa, dalam model pembelajaran lebih memperhatikan model penemuan terbimbing (assisted discovery) yang berkembang melalui latihan terbimbing, pengajaran responsive, performansi terbimbing, dan dialog Sokrates di antara peserta didik. Dengan demikian, strategi menulis terbimbing (SMT) merupakan strategi pembelajaran yang dilakukan melalui cara yang ditempuh oleh dosen kepada mahasiswa dalam bentuk pemberian bimbingan dan dilakukan melalui tanya jawab.

Guna memahamkan kepada mahasiswa sebagai calon penulis CA, perlunya dipilih contoh cerita anak karya orang lain (CAKOL) yang sudah memenuhi sebagai cerita yang baik untuk bahan pembelajaran. Hal ini sebagai dasar dalam mentukan langkah pembelajaran menulis CA. Menujuk Tompkins (1994:218) langkah-langkah dalam pembelajaran menulis CA yaitu: (a) membaca cerita, (b) membicarakan/mendiskusikan cerita, (c) mengisahkan kembali cerita, (d) mengkaji struktur cerita, dan (e) menulis cerita.

Berdasarkan sejumlah hal di atas, dalam proses menulis terjadi proses berpikir, terjadi proses pengenalan konsep baru, terjadi proses penyesuaian dengan konsep sebelumnya. Untuk itu, dasar teori belajar yang digunakan adalah: teori belajar Vigotsky, teori kognitif Piaget, dan teori Ausubel tentang belajar bermakna.

Zone of Proximal Development (ZPD) adalah konsep belajar dari Vigotsky, yang menekankan hubungan antara pembelajaran (learning) dan perkembangan (development). Dinyatakan Vigotsky (dalam Bodrova, 1996: 35) bahwa kepandaian dan tingkah laku yang digambarkan bersifat dinamis dan terus menerus berkembang. Apa yang dikerjakan anak hari ini dengan bantuan, adalah apa yang akan dilakukan anak secara mandiri esok hari. Apa yang dibutuhkan anak hari ini adalah bantuan dan dukungan penuh, ini akan menjadikan anak esok hari dapat melakukan sesuatu dengan bantuan minimal. Dengan bantuan itulah tingkat prestasi anak berubah meningkat seiring dengan perkembangannya.

Skema, adalah pola tingkah laku yang dapat di ulang-ulang dan sifatnya teratur. Skema berhubungan dengan tingkah laku yang dapat diamati dan tingkah laku yang tidak dapat diamati. Piaget percaya bahwa anak-anak mengembangkan skema dari yang ada di dunia ini dan mempertahankan masalah penting (outlines) dalam ingatan mereka (Dworetzky, 1990:243). Dinyatakan Piaget bahwa proses berpikir seseorang dipengaruhi oleh pengalaman 
dari lingkungan dan kematangannya, yakni sebagai aktivitas bertingkat dari fungsi intelektual mulai konkrit menuju abstrak. Jadi, menurut Piaget untuk memperlakukan anak sebagai objek didasarkan pada tahapan berpikirnya, agar pembelajaran lebih bermakna.

Dikatakan Ausubel, Novak, dan Hanesian (1978: 23) bahwa, belajar bermakna merupakan suatu proses mengaitkan informasi baru pada konsep-konsep yang relevan yang terdapat pada struktur kognitif seseorang. Ausubel selanjutnya mengatakan bahwa, sesuatu yang meaningful atau bermakna dapat diambil dari suatu bahan bacaan yang dibaca atau sesuatu yang berada di luar diri siswa/pebelajar/ mahasiswa. Menurutnya, materi yang disajikan melalui bacaan dan hal-hal lain yang dialami siswa dapat saja menjadi sesuatu yang bermakna. Morrow, (via Spodek, 1994: 325-326) juga menyatakan bahwa "Reading is related to writing. In writing, meaning is constructed by constructing teks, while in reading teks is constructed through anticipating meaning". Sehubungan dengan hal di atas, tampak bahwa keterampilan membaca berhubungan dengan keterampilan menulis. Dalam menulis, makna dibentuk dengan membangun teks, sementara dalam membaca, teks dibangun melalui pemahaman makna. Oleh karena itu, untuk kepentingan dalam penelitian ini, mahasiswa sebelum melakukan kegiatan menulis, melakukan kegiatan membaca terlebih dahulu.Untuk itu, agar tidak terjadi salah konsep, perlu bimbingan.

Bimbingan yang diberikan dosen kepada mahasiswa pada dasarnya merupakan pembuka jalan untuk mencapai tingkat kemampuan menulis secara mandiri. Hal tersebut sesuai yang dikatakan Vygotsky melalui Gunning (1992: 400) tentang teori scaffoldingnya. Menurut Vygotsky bimbingan yang diberikan guru/dosen kepada siswa/mahasiswa hanya berfungsi sebagai tangga untuk memperkuat potensi siswa/ mahasiswa untuk mencapai tingkat kemampuan maksimal. Bila tangga tersebut telah kuat, siswa/mahasiswa siap menjadi penulis mandiri, dalam hal ini mampu menulis CA secara mandiri.

Cerita anak adalah sebuah cerita yang didasarkan pada penggunaan pandangan anak. Masalah yang diceritakan tidak selalu dunia anak, namun dapat juga dari dunia remaja, orang dewasa, bahkan orang tua. Dalam menghadirkan ceritanya selalu didasarkan pada tingkatan perkembangan usia anak. Oleh karena itu, CA memiliki unsur: (1) tema dan amanat, (2) tokoh dan penokohan,(3) alur, (4) seting/ latar tempat, (5) seting suasana, (6) seting waktu, (7) sudut pandang, dan (8) gaya penceritaan, (9) ekstrinsik, (10) pendahuluan, (11) inti, dan (12) penutup.

Di samping itu juga memiliki ciri-ciri yang khas, yaitu adanya: (1) unsur yang berkenaan dengan tema dan amanat, (2) gaya penceritaan secara langsung ditampilkan dalam konteks dunia anak-anak. Oleh karenanya CA hendaklah memiliki tema dan amanat yang jelas, cerita tidak berbelit-belit, dan disajikan berdasarkan kacamata anak. Memiliki isi yang mampu: memberi pengalaman (rasa, emosi, bahasa); (kognitif, sosial, etis, spiritual); eksplorasi dan penemuan, petualangan dan kenikmatan, Saxby \& Winch (1991: 5-10). Semua karakteristik dalam CA itu, mahasiswa hendaklah mampu dalam penulisannya.

Kemampuan menulis CA adalah suatu kecakapan seseorang dalam menuangkan gagasannya dalam bentuk cerita untuk anak. Kemampuan itu selain didukung oleh seluruh keterampilan berbahasa, memahami karakteriktik CA, kejiwaan anak, juga kemampuan berpikir, dan kemampuan menata gagasan. Dalamhalinidilakukan melalui Strategi Menulis Terbimbing.

Moore (1986: 106-114) menyatakan bahwa pembelajaran menulis terbimbing (Guided writing lessons) harus terkait 
antara isi dengan materi,dilakukan secara bertahap, peran guru/dosen semakin lama semakin berkurang. Jadi, strategi menulis terbimbing dibutuhkan: pembimbing/ guru/dosen dan siswa/mahasiswa yang aktif selama pembelajaran berlangsung, adanya proses, tujuan, dilakukan secara kontinyu/terus menerus dan bertahap, dan terjadi perubahan dalam setiap tahapan. Menurut Tompkins dan Hoskinson (1995:330) langkah pembelajarannya adalah: (1) mengenalkan tentang elemen/ unsur cerita, (2) menganalisis unsur cerita, (3) mengungkap isi cerita, dan (4) mereview sebuah cerita.

Untuk melihat kemampuan mahasiswa dalam menulis CA tersebut, diperlukan pedoman penilaiannya. Pedoman penilaian ini digunakan skala analitik dari Paul Diederich 1974; Cooper 1975; dan Saders dan Littlefield, 1975 (Cooper C.R. \& Lee O., 1977), yang diadaptasi dari Tompkins (1994:391-392) seperti disajikan pada Tabel 1.

Berdasarkan uraian di atas, penelitian ini bertujuan agar proses pembelajaran peningkatan kemampuan mahasiswa dalam menulis CA melalui SMT dilaksanakan yang dilaksanakan dosen meningkat, dan kemampuan mahasiswa dalam menulis CA melalui SMT yang telah dilaksanakan mengalami peningkatan.

\section{METODE}

Penelitian ini adalah jenis penelitian tindakan kelas. Model yang digunakan adalah disain Kemmis dan Mc Taggart (1998). Desain ini dilakukan melalui empat tahapan esensial, yakni tahap: (1) perencanaan tindakan, (2) pelaksanaan tindak-

Tabel 1. Kriteria Penilaian Kemampuan Mahasiswa dalam Menulis CA

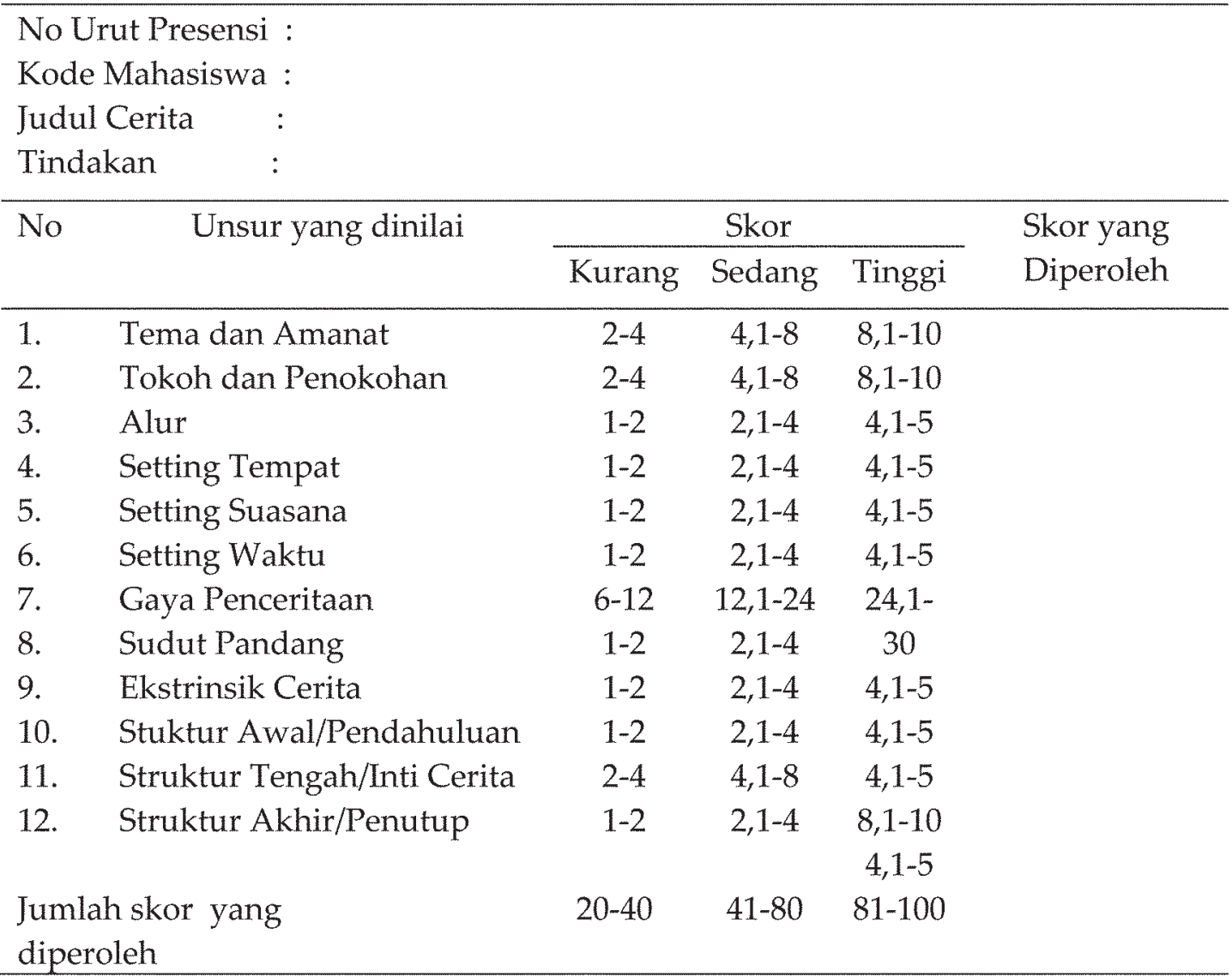

Sumber: Cooper dan Odell, (ed). 1977 dan Tompkins, 1994. 
an, (3) pengamatan tindakan, dan (4) perefleksian.

Sumber data adalah peneliti, dosen Bahasa Indonesia lain yang berperan sebagai kolaborator. Mahasiswa kelas A6 semester III, dan siswa dari tiga SD di SD kota dan SD di desa. Teknik pengumpulan data yang digunakan adalah: (1) tes kemampuan menulis mahasiswa, (2) wawancara dosen dan mahasiswa, (3) observasi, (4) catatan lapangan, (5) foto/ vidio, (6) portofolio, dan (7) angket mahasiswa. Instrumen yang digunakan adalah: (1) materi/bahan pembelajaran menulis CA, (2) CAKOL, (3) format observasi dan atau catatan lapangan, (4) format lembar tugas kelompok untuk menganalisis CAKOL, (5) angket bahasa tentang penguasaan penulisan CA, (6) wawancara dosen, (7) hasil penulisan CA karya mahasiswa dari TA sampai Tes Akhir Siklus III, (8) kamera foto/vidio. Analisis data yang digunakan adalah model analisis alur Milles and Huberman (1992: 16-20). Oleh karena data yang terkumpul diperlukan tabel dan grafik, maka analisis data yang digunakan statistika deskriptif. Keabsahan data dalam penelitian ini mengacu pada penelitian kualitatif yang dikemukakan Guba (1981) yang dikutip Milles (2003: 78) yakni digunakan langkah: (1) credibility, (2) transferability, (3) dependability, dan (4) confirmability.

\section{HASIL DAN PEMBAHASAN Hasil Penelitian}

Dari hasil pengamatan awal terhadap pelaksanaan pembelajaran yang telah dilakukan peneliti, disimpulkan bahwa dosen masih kurang memberi penekanan secara mendalam pada unsur-unsur CA dan unsur kebahasaan, serta kurang memberikan pengalaman langsung yang sifatnya aplikatif. Di samping itu, mahasiswa kurang mendapat bimbingan secara maksimal. Hal ini tampak saat dosen bersama mahasiswa melaksanakan pembelajaran, hingga dilakukan kegiatan menulis CA sebagai tes awal. Untuk itu, dirancang tindakan siklus I.

Rencana tindakan Siklus I ini adalah: (1) memberikan pembekalan materi karakteristik CA, dan karakteristik Anak SD. (2) memberikan pembekalan unsur kebahasaan dan struktur cerita berdasarkan CAKOL, (3) menyusun sinopsis berdasarkan CAKOL. Langkah (1), (2), dan (3) dilakukan secara terbimbing, sedangkan langkah (4) melakukan penulisan CA secara mandiri berdasarkan tes awal.

Rincian proses Tindakan Siklus I sebagai berikut. Pertemuan kesatu, pembacaan CAKOL secara individual, pembekalan materi karakteristik CA, pembekalan unsur instrinsik CA dan ekstrinsik CA melalui tanya jawab, diskusi kelompok, dan presentasi hasil diskusi kelompok tentang unsur-unsur CA. Pertemuan kedua, pembacaan CAKOL secara individual, tanya jawab dan diskusi tentang unsur kebahasaan dan struktur cerita, diskusi kelompok, dan presentasi hasil diskusi. Pertemuan ketiga, pembacaan CAKOL, penyusunan Sinopsis dari CAKOL yang sudah dibaca. Pertemuan ke 1, 2,dan 3 dilakukan secara terbimbing. Pertemuan keempat, Tes Akhir Siklus I secara mandiri berdasarkan tes awal penulisan CA.

Kemampuan mahasiswa dalam menulis CA dari Tes Awal ke Siklus I mengalami peningkatan perolehan skor. Pada Tes Awal, mahasiswa yang berada pada tingkat kemampuan (TK) kurang sejumlah 20 orang, pada Tes Siklus I berkurang menjadi 5 mahasiswa. Untuk TK sedang, Tes Awal berjumlah 7 mahasiswa, pada Siklus I menjadi 22 mahasiswa. Untuk TK Tinggi, baik hasil Tes Awal maupun Tes Siklus I belum ada mahasiswa yang memiliki TK Tinggi.

Peningkatan kemampuan kelas dalam memaparkan unsur CA dari Tes Awal ke Tes Akhir Sklus I sudah mulai tampak. Untuk TK Tinggi pada Tes Awal 0,3\%, setelah Siklus I meningkat menjadi 0,9\%. Untuk TK Sedang pada Tes Awal 31,7\%, 
setelah Siklus I meningkat menjadi 53\%. Untuk TK Kurang pada Tes Awal 68\%, setelah Siklus I meningkat menjadi tinggal $45,9 \%$.

Refleksi tindakan Siklus I ini, bahwa peningkatan kemampuan mahasiswa dalam menulis CA dari Tes Awal ke Tes Siklus I sudah tampak. Mahasiswa yang memiliki skor TK Tinggi masih 0\% dan kemampuan kelas dalam memaparkan unsur CA pada TK Tinggi baru 0,9\%. Ini berarti masih terdapat masalah dan perlu tindakan yang lebih baik.

Masalah yang ditemukan dari hasi refleksi Siklus I sebagai berikut. Pertama, pemaparan unsur tema dan amanat, perlu kesesuaian antara judul dan esensi cerita yang akan disampaikan. Kedua, pemaparan unsur tokoh dan penokohan, perlukarakter tokoh yang mendidik. Ketiga, pemaparan unsur alur cerita, hendaklah alurmaju. Keempat, pemaparan unsur seting tempat, hendaklah jelas di mana peristiwa itu terjadi. Kelima, pemaparan unsur seting suasana hendaklah memperhatikan bagaimana dan dalam situasi apa peritiwa itu berlangsung. Keenam, pemaparan seting waktu, hendaklah jelas kapan cerita itu berlangsung. Ketujuh, pemaparan unsur gaya penceritaan, hendaklah memperhatikan untuk siapa cerita itu disuguhkan. Kedelapan, pemaparan unsur sudut pandang karena cerita yang dihasilkan oleh mahasiswa semua untuk anak SD kelas tinggi, maka sudut pandang orang ketiga lebih pas. Kesembilan, pemaparan unsur ekstrinsik cerita, hendaklah mampu memberikan efek positippada anak. Kesepuluh, pemaparan unsur struktur cerita pendahuluan, hendaklah memperhatikan pengenalan tokoh dan tanda-tanda terjadinya konflik. Kesebelas, pemaparan unsur struktur inti cerita, hendaklah ada unsur yang mendidik, walaupun terjadi pertengkaran. Keduabelas, pemaparan struktur cerita bagian penutup, perlu ditampilkan masalah yang mendidik, menyenangkan, dan tidak menimbulkan dendam pada anak.
Permasalahan yang muncul berdasarkan refleksi Siklus I di atas, disebabkan oleh tiga hal, yaitu: (1) dosen belum memberikan bimbingan kepada mahasiswa secara optimal. (2) Dosen masih dibingungkan oleh cara pembimbingan dengan ruangan yang sempit, dan (3) mahasiswa belum memanfaatkan dosen sebagai pembimbing secara optimal. Untuk itu, dirancang Rencana Tindakan Siklus II sebagai upaya mengatasi permasalahan tersebut.

Deskripsi Rencana Tindakan Siklus II sebagai berikut. Pertama, melakukan pembekalan materi unsur instrinsik dan ekstrinsik secara terbimbing. Kedua, melakukan pembekalan unsur kebahasaan dan struktur cerita secara terbimbing. Ketiga, menganalisis CA karya mahasiswa berkelompok secara terbimbing. Keempat, menulis CA secara mandiri berdasarkan Tes Akhir Siklus I.

Deskripsi Tindakan Siklus II sebagai berikut. Pertemuan kesatu, pembacaan CAKOL secara individual, dilanjutkan pembekalan unsur instrinsik CA dan ekstrinsik CA melalui tanya jawab dan diskusi kelompok, presentasi hasil diskusi. Pertemuan kedua, pembacaan CAKOL, dilanjutkan dengan tanya jawab dan diskusi. presentasi hasil diskusi kelompok. Pertemuan ketiga, pembacaan CA karya mahasiswa yang akan didiskusikan secara berkelompok. Tugas ini mahasiswa menganalisis unsur-unsur CA secara keseluruhan. Pertemuan 1,2, dan 3 dilakukan secara terbimbing. Pertemuan keempat, dilakukan Tes Akhir penulisan CA Siklus II secara mandiri berdasarkan hasil Tes Akhir Siklus I. Tes berlangsung di dalam kelas dan atau di luar kelas.

Dari tes akhir Siklus I ke Siklus II mahasiswa memperoleh peningkatan skor. Mahasiswa yang memiliki TK kurang, Tes Siklus I berjumlah 5 orang, Tes Siklus II menjadi 0 mahasiswa. Mahasiswa yang memiliki TK sedang, Tes Siklus I berjumlah 22 orang, Tes Siklus II menjadi 
26 orang.Mahasiswa yang memiliki TK Tinggi, Tes Siklus I terdapat 0 mahasiswa, Tes Siklus II menjadi 1 orang.

Peningkatan kemampuan mahasiswa dalam memaparkan unsur CA dari Tes Siklus I ke Siklus II sudah mulai tampak. Mahasiswa yang memiliki TK Tinggi Siklus I sebesar 0,9\%, Siklus II menjadi 9,9\%. Mahasiswa yang memiliki TK Sedang Tes Siklus I sebesar 53\%, Siklus II menjadi $79 \%$. Mahasiswa yang memiliki TK Kurang Tes Siklus I sebesar 45,9\%, Siklus II meningkat menjadi tinggal $11,1 \%$.

Refleksi Tindakan Siklus II, menunjukkan bahwa peningkatan kemampuan mahasiswa dalam menulis CA dari Tes Siklus I ke Siklus II ini sudah tampak, namun belum memuaskan. Skor TK Tinggi masih 3,7\% dan kemampuan kelas dalam memaparkan unsur CA pada TK Tinggi baru 9,9\%. Berarti masih terdapat masalah dan perlu tindakan yang lebih baik. Masalah yang ditemukan, yaitu: (1) pemaparan seting waktu, hendaklah memperhatikan kapan peristiwa itu terjadi; (2) pemaparan unsur gaya penceritaan, hendaklah memperhatikan untuk siapa cerita itu disuguhkan; (3) pemaparan unsur ekstrinsik cerita, hendaklah jelas dalam memaparannya; (4) pemaparan unsur pendahuluan, hendaklah memperhatikan tanda-tanda terjadinya konflik; (5) pemaparan unsur struktur inti cerita, hendaklah menghibur, menyenangkan; dan (6) pemaparan unsur penutup, perlu ditampilkan masalah yang mendidik dan menyenangkan.

Permasalahan yang muncul berdasarkan refleksi Siklus II di atas, disebabkan oleh tiga hal, yaitu: (1) mahasiswa belum memanfaatkan dosen sebagai pembimbing secara optimal, (2) tes Siklus II yang dilakukan di luar kelas dan atau di dalam kelas masih kurang kondusif. Dengan demikian, perlu dilakukan penulisan CA di rumah masing-masing mahasiswa agar lebih konsentrasi dalam penulisannya. Tindakan Siklus II masih dianggap ada masalah, untuk itu disusun rencana tindakan Siklus III.

Deskripsi Rencana Tindakan Siklus III sebagai berikut. Pertemuan kesatu, pemantapan materi unsur: seting cerita, gaya penceritaan, ekstrinsik cerita, dan struktur cerita. Pertemuan kedua, penulisan CA secara mandiri dikerjakan di rumah masing-masing mahasiswa. Diketik komputer Arial 12, hasilnya diserahkan dalam bentuk print-out dan disertai soft-copy.

Proses tindakan Siklus III sebagai berikut. Pertemuan kesatu, pembacaan CAKOL secara individual, pemantapan pemahaman materi tentang unsur seting cerita, gaya penceritaan, ekstrinsik cerita dan struktur cerita. Dilakukan melalui diskusi, tanya jawab, dan presentasi secara terbimbing. Pertemuan kedua, penulisan CA secara mandiri dikerjakan di rumah masing-masing mahasiswa. Diserahkan ke dosen keesokan harinya dalam bentuk print-out dan soft-copy.

Mahasiswa dalam menulis CA dari Tes Siklus II ke Tes Siklus III telah mengalami peningkatan skor. Tidak ada lagi mahasiswa yang memiliki TK Kurang. Mahasiswa yang memiliki TK Sedang, pada hasil Tes Siklus II berjumlah 26 mahasiswa, Siklus III menjadi tinggal 15 mahasiswa.TK Tinggi, pada Tes Siklus II terdapat 1 mahasiswa, pada Tes Siklus III meningkat menjadi 12 mahasiswa. Peningkatan kemampuan mahasiswa dalam memaparkan unsur CA dari Tes Siklus II ke Siklus III sudah tampak. Mahasiswa yang memiliki TK Tinggi Tes Siklus II sebesar 9,9\%, setelah Siklus III meningkat $57 \%$. TK Sedang Tes Siklus II sebesar 79\%, setelah Siklus III meningkat tinggal 43\%. TK Kurang Tes Siklus II sebesar 11,1\%, setelah Siklus III meningkat menjadi 0\%.

Peningkatan kemampuan mahasiswa dalam menulis CA dari Tes Awal sampai Tes Akhir Siklus III, tampak sekali. Peningkatan perolehan skors sebagai berikut. Pertama, untuk skor 81-100 (TK Tinggi) sejak Tes Awal sampai Tes S-II 
tidak ada mahasiswa yang bertingkat kemampuan Tinggi. Siklus-III terdapat 12 mahasiswa yang bertingkat kemampuan Tinggi. Kedua, untuk skor 41-80 (TK Sedang) pada TA terdapat 7 mahasiswa, setelah dilakukan tes akhir tindakan Siklus I meningkat menjadi 22 mahasiswa, pada S-II terdapat 26 mahasiswa, dan pada S-III tinggal 15 mahasiswa. Ketiga, untuk skor 20-40 (TK Kurang) pada TA terdapat 20 mahasiswa, pada S-I berkurang menjadi 5 mahasiswa, S-II dan siklus III 0 mahasiswa yang berarti tidak ada lagi mahasiswa di TK kurang. Gambaran peningkatan skor tersaji pada Grafik 1 dan hasil peningkatan skor tersaji pada Tabel 2.

Peningkatan kemampuan mahasiswa dalam memaparkan unsur CA dari Tes Awal sampai Siklus III peningkatannya dipaparkan berikut. Pertama, skor TK Tinggi: pada tahap Tes Awal baru dicapai 0,3\%, pada Silus-I 0,9\%, pada Siklus-II 9,9\%, dan pada S-III meningkat menjadi 57\%. Kedua, skor TK Sedang: pada tahap Tes Awal sudah mencapai 32,7 \%, pada Siklus-I 53,3\%, pada Siklus-II 79\%, dan pada S-III menjadi $43 \%$. Ketiga, skor TK Kurang: pada tahap Tes Awal $67 \%$, pada S-I berkurang menjadi $45,6 \%$, pada Siklus-II menurun lagi menjadi $11,1 \%$, dan pada S-III tinggal $0 \%$ atau tidak ada lagi. Hal tersebut tersaji pada tabel 3 di bawah ini.

\section{Pembahasan}

Penerapan pembelajaran menulis melalui SMT ini memerlukan dukungan dosen bahasa Indonesia yang lain, betapa pembelajaran dengan strategi ini dapat meningkatkan kemampuan menulis CA pada mahasiswa. Hal ini karena mahasiswa diberi kesempatan untuk menuangkan gagasan secara bebas dengan menggunakan bahasanya sendiri namun tetap dibimbing oleh dosen. Pembimbingan dengan cara: (1) memaparkan unsur tema dan amanat perlu kesesuaian antara judul dan esensi cerita yang akan disampaikan, (2) memaparkan unsur tokoh dan penokohan perlukarakter tokoh yang mendidik, (3) memaparkan unsur alur cerita, hendaklah alur maju, (4) memaparkan unsur seting tempat hendaklah jelas di mana peristiwa itu terjadi, (5) memaparkan unsur seting suasana hendaklah memperhatikan bagaimana dan dalam situasi apa peritiwa itu berlangsung, (6) memaparkan seting waktu, hendaklah jelas kapan cerita itu berlangsung, (7) memaparkan unsur gaya penceritaan, hendaklah memperhatikan untuk siapa cerita itu disuguhkan, (8) memaparkan unsur

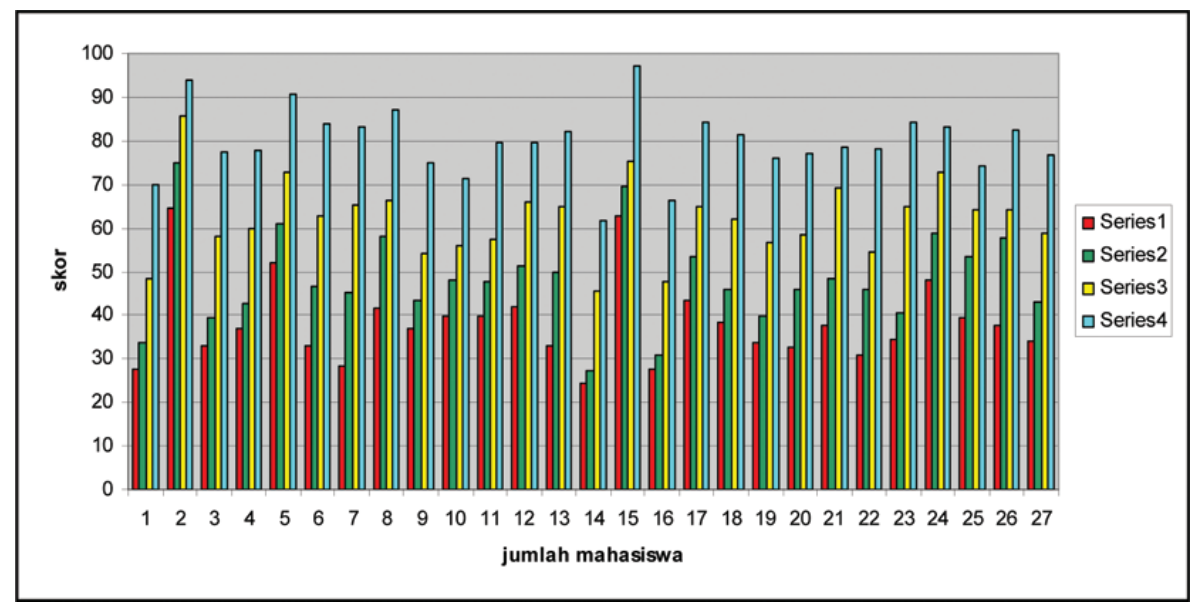

Grafik 1.

Gambaran Peningkatan Skor Kemampuan Mahasiswa dalam Menulis CA dari Tes Awal Sampai dengan Tes Akhir Siklus III. 
sudut pandang karena cerita yang dihasilkan oleh mahasiswa semua untuk anak SD kelas tinggi, maka sudut pandang orang ketiga lebih pas, (9) memaparkan unsur ekstrinsik cerita, hendaklah mampu memberikan efek positif pada anak, (10) memaparkan unsur struktur cerita pendahuluan, hendaklah memperhatikan pengenalan tokoh dan tanda-tanda terjadinya konflik, (11) memaparkan unsur struktur inti cerita, hendaklah ada unsur yang mendidik,walaupun terjadi pertengkaran, dan dalam (12) memaparkan struktur cerita bagian penutup, perlu ditampilkan masalah yang mendidik, menyenangkan dan tidak menimbulkan dendam pada anak.

Pembimbingan ini walaupun melalui proses yang dilakukan secara bertahap dan berulang-ulang, mulai dari prosedur: membaca CAKOL, mendiskusikan CAKOL tentang unsur-unsur cerita, menyusun sinopsis berdasarkan CAKOL yang telah dibaca dan menulis CA secara mandiri berdasarkan Tes Awal baik langsung maupun tidak langsung mampu meningkatkan kemampuan mahasiswa dalam menulis CA. Membaca CAKOL se-

Tabel 2. Hasil Peningkatan Skor Kemampuan Mahasiswa dalam Menulis CA dari Tes Awal sampai Tes Akhir Siklus III

\begin{tabular}{|c|c|c|c|c|c|c|c|c|c|c|c|c|c|}
\hline \multirow[t]{3}{*}{ No } & \multirow{3}{*}{$\begin{array}{l}\text { Nama } \\
\text { Inisial } \\
\text { Mhs }\end{array}$} & \multicolumn{12}{|c|}{ Hasil Peningkatan Skor } \\
\hline & & \multicolumn{4}{|c|}{ Tinggi (81-100) } & \multicolumn{4}{|c|}{ Sedang (41-80) } & \multicolumn{4}{|c|}{ Kurang (20-40) } \\
\hline & & TA & SI & SII & SIII & TA & SI & SII & SIII & $\mathrm{TA}$ & SI & SII & SIII \\
\hline 1. & DAN & - & - & - & - & - & - & V & V & V & $\mathrm{V}$ & - & - \\
\hline 2. & ADY & - & - & $\mathrm{V}$ & V & $\mathrm{V}$ & V & - & - & - & - & - & - \\
\hline 3. & NUN & - & - & - & - & - & - & V & V & V & $\mathrm{V}$ & - & - \\
\hline 4. & SIW & - & - & - & - & - & V & $\mathrm{V}$ & $\mathrm{V}$ & V & - & - & - \\
\hline 5. & FIT & - & - & - & V & V & V & V & - & - & - & - & - \\
\hline 6. & AFF & - & - & - & V & - & V & $\mathrm{V}$ & - & $\mathrm{V}$ & - & - & - \\
\hline 7. & ATI & - & - & - & V & - & V & $\mathrm{V}$ & - & V & - & - & - \\
\hline 8. & PAR & - & - & - & V & V & V & $\mathrm{V}$ & - & - & - & - & - \\
\hline 9. & NAT & - & - & - & - & - & V & V & V & V & - & - & - \\
\hline 10. & PRA & - & - & - & - & - & V & V & V & V & - & - & - \\
\hline 11. & ANI & - & - & - & - & - & V & V & V & V & - & - & - \\
\hline 12. & NOV & - & - & - & - & V & V & V & V & - & - & - & - \\
\hline 13. & SUL & - & - & - & V & - & V & V & - & V & - & - & - \\
\hline 14. & MUH & - & - & - & - & - & - & V & V & V & $\mathrm{V}$ & - & - \\
\hline 15. & DHA & - & - & - & V & V & V & V & - & - & - & - & - \\
\hline 16. & LUT & - & - & - & - & - & - & V & V & V & V & - & - \\
\hline 17. & TEN & - & - & - & V & V & V & V & - & - & - & - & - \\
\hline 18. & LIS & - & - & - & V & - & V & V & - & V & - & - & - \\
\hline 19. & RIR & - & - & - & - & - & - & V & V & V & V & - & - \\
\hline 20. & WAH & - & - & - & - & - & V & V & V & V & - & - & - \\
\hline 21. & RAR & - & - & - & - & - & V & V & V & V & - & - & - \\
\hline 22. & UMI & - & - & - & - & - & V & V & V & V & - & - & - \\
\hline 23. & BUN & - & - & - & $\mathrm{V}$ & - & V & V & - & V & - & - & - \\
\hline 24. & IND & - & - & - & V & V & V & V & - & - & - & - & - \\
\hline 25. & ERY & - & - & - & - & - & V & V & V & V & - & - & - \\
\hline 26. & TIT & - & - & - & V & - & V & V & - & V & - & - & - \\
\hline 27. & ANA & - & - & - & - & - & V & V & V & V & - & - & - \\
\hline \multicolumn{2}{|c|}{$\begin{array}{l}\text { Jumlah Mhs } \\
\text { Jumlah }\end{array}$} & 0 & 0 & 1 & 12 & 7 & 22 & 26 & 15 & 20 & 5 & 0 & 0 \\
\hline \multicolumn{2}{|c|}{ Persentase } & 0 & 0 & 3,7 & 44 & 25,9 & 81,4 & 96,3 & 56 & 74,1 & 18,6 & 0 & 0 \\
\hline
\end{tabular}


Tabel 3. Peningkatan Memaparkan Unsur CA dari Tes Awal sampai ke Tes Akhir Siklus 3

\begin{tabular}{|c|c|c|c|c|c|c|}
\hline \multirow[t]{2}{*}{ No } & \multirow[t]{2}{*}{ Unsur Cerita } & \multirow[t]{2}{*}{$\begin{array}{l}\text { Tingkat } \\
\text { Kemampuan }\end{array}$} & \multicolumn{4}{|c|}{$\begin{array}{l}\text { Tahapan dan Jumlah Mahasiswa yang } \\
\text { mampu Memaparkan Unsur CA }\end{array}$} \\
\hline & & & $\mathrm{TA}$ & S-I & S-II & S-III \\
\hline \multirow[t]{3}{*}{1.} & Tema dan & $\mathrm{T}$ & 0 & 0 & 1 & 12 \\
\hline & amanat & S & 5 & 14 & 26 & 15 \\
\hline & & K & 22 & 13 & 0 & 0 \\
\hline \multirow[t]{3}{*}{2.} & Tokoh dan & $\mathrm{T}$ & 0 & 0 & 1 & 13 \\
\hline & penokohan & $S$ & 10 & 18 & 26 & 14 \\
\hline & & K & 17 & 9 & 0 & 0 \\
\hline \multirow[t]{3}{*}{3.} & Alur & $\mathrm{T}$ & 0 & 0 & 5 & 21 \\
\hline & & S & 11 & 19 & 22 & 6 \\
\hline & & $\mathrm{K}$ & 16 & 8 & 0 & 0 \\
\hline \multirow[t]{3}{*}{4.} & Seting tempat & $\mathrm{T}$ & 0 & 0 & 3 & 16 \\
\hline & & $S$ & 13 & 18 & 24 & 11 \\
\hline & & K & 14 & 9 & 0 & 0 \\
\hline \multirow[t]{3}{*}{5.} & Seting suasana & $\mathrm{T}$ & 0 & 0 & 4 & 19 \\
\hline & & $S$ & 13 & 20 & 23 & 8 \\
\hline & & K & 14 & 7 & 0 & 0 \\
\hline \multirow[t]{3}{*}{6.} & Seting waktu & $\mathrm{T}$ & 0 & 0 & 1 & 9 \\
\hline & & $S$ & 9 & 13 & 21 & 18 \\
\hline & & K & 18 & 14 & 5 & 0 \\
\hline \multirow[t]{3}{*}{7.} & Gaya & $\mathrm{T}$ & 0 & 0 & 2 & 11 \\
\hline & penceritaan & S & 4 & 10 & 22 & 16 \\
\hline & & $\mathrm{K}$ & 23 & 17 & 3 & 0 \\
\hline \multirow[t]{3}{*}{8.} & Sudut pandang & $\mathrm{T}$ & 0 & 1 & 11 & 21 \\
\hline & & $S$ & 16 & 24 & 16 & 6 \\
\hline & & K & 11 & 2 & 0 & 0 \\
\hline \multirow[t]{3}{*}{9.} & Ekstrinsik & $\mathrm{T}$ & 1 & 2 & 4 & 18 \\
\hline & & $S$ & 12 & 14 & 19 & 9 \\
\hline & & $\mathrm{K}$ & 14 & 11 & 4 & 0 \\
\hline \multirow[t]{3}{*}{10.} & Struktur & $\mathrm{T}$ & 0 & 0 & 0 & 14 \\
\hline & pendahuluan & $\mathrm{S}$ & 3 & 7 & 21 & 13 \\
\hline & & K & 24 & 20 & 6 & 0 \\
\hline \multirow[t]{3}{*}{11.} & Struktur inti & $\mathrm{T}$ & 0 & 0 & 0 & 14 \\
\hline & & S & 4 & 8 & 19 & 13 \\
\hline & & $\mathrm{K}$ & 23 & 19 & 8 & 0 \\
\hline \multirow[t]{3}{*}{12.} & Struktur & $\mathrm{T}$ & 0 & 0 & 0 & 16 \\
\hline & penutup & $S$ & 3 & 8 & 22 & 11 \\
\hline & & $\mathrm{K}$ & 24 & 19 & 5 & 0 \\
\hline \multirow{3}{*}{\multicolumn{2}{|c|}{$\begin{array}{l}\text { Tingkat kemampuan } \\
\text { kelas dalam persen }\end{array}$}} & $\mathrm{T}$ & $0,3 \%$ & $0,9 \%$ & $9,9 \%$ & $57 \%$ \\
\hline & & S & $31,7 \%$ & $53,3 \%$ & $79 \%$ & $43 \%$ \\
\hline & & K & $68 \%$ & $5,6 \%$ & $11,1 \%$ & $0 \%$ \\
\hline \multicolumn{2}{|c|}{ Jumlah persentase } & TSK & $100 \%$ & $100 \%$ & $100 \%$ & $100 \%$ \\
\hline
\end{tabular}

cara individu dalam pembelajaran menulis CA yang dilakukan secara terbimbing baik langsung maupun tidak langsung mampu memahamkan mahasiswa tentang unsur-unsur CA, tentang konsep dasar dalam menulis CA. Mendiskusi- kan CAKOL tentang unsur-unsur cerita berdasarkan CAKOL yang telah dibaca dan dilakukan secara terbimbing, baik langsung maupun tidak langsung pula mampu meningkatkan kemampuan mahasiswa dalam memahami konsep dasar 
CA, unsur-unsur CA, dan meningkatkan kemampuan menulis CA.

Menyusun sinopsis berdasarkan CAKOL yang telah dibaca secara individu dalam pembelajaran menulis CA yang dilakukan secara terbimbing baik langsung maupun tidak langsung mampu memberikan pengalaman menulis berdasarkan pemahaman unsur-unsur CA, konsep dasar CA, konsep dasar menulis CA, dan mampu meningkatkan kemampuan mahasiswa dalam menulis CA. Menulis CA yang dilakukan secara mandiri merupakan implementasi praktis dari sejumlah pengetahuan dan pemahaman yang telah dimiliki mahasiswa setelah mendapatkan bimbingan dari dosen. Jadi, penerapan pembelajaran menulis melalui SMT dapat diimplementasikan sebagai alternatif pada matakuliah Bahasa Indonesia khususnya pada pembelajaran menulis di PGSD.

\section{SIMPULAN}

Penggunaan SMT sebagai strategi pembelajaran ternyata efektif meningkatan kemampuan mahasiswa dalam menulis cerita anak. Cara yang ditempuh sebagai berikut. Pertama, membaca CAKOL dilakukan secara individual mampu memahamkan mahasiswa tentang unsur-unsur CA. Pemahaman mahasiswa terhadap unsur-unsur cerita, akhirnya kemampuan mahasiswa dalam menulis CA semakin meningkat. Kedua, mendiskusikan CAKOL yang telah dibaca untuk menganalisis unsur-unsur cerita secara terbimbing. Proses diskusi dalam berkelompok yang dilakukan secara terbimbing itulah terjadi tukar pendapat tentang hal-hal yang berkaitan dengan pengetahuan yang telah dimiliki. Ketiga, mengisahkan kembali cerita berdasarkan CAKOL yang telah dibaca yang dilakukan secara terbimbing, mampu memahamkan mahasiswa terhadap bentuk tulisan, apa yang akan ditulis, dan bagaimana caranya menulis. Keempat, menulis cerita secara mandiri merupakan muara dari prose- dur dalam SMT. Pemahaman mahasiswa tentang unsur-unsur cerita, isi cerita, dan bagaimana caranya menulis cerita, mahasiswa semakin tinggi tingkat kemampuan menulisnya.

Strategi pembimbingan dalam penelitian ini memberikan kesempatan kepada mahasiswa untuk memahami secara individual bagaimana cara menulis CA. Dengan kemampuan memaparkan unsurunsur cerita tersebut, skor hasil menulis CA yang telah dilakukan mahasiswa pun semakin meningkat.

Peningkatan kemampuan mahasiswa dalam menulis CA dari Tes Awal sampai tindakan Siklus III mengalami peningkatan skor. Hal itu terbukti dari pencapaian skor rata-rata Tes Awal sebesar 38,26, Tes Akhir Siklus I sebesar 48,22, Tes Akhir Siklus II sebesar 62,09, dan setelah dilakukan tindakan Siklus III meningkat, dengan rata-rata skor menjadi sebesar 79,70.

Dari mahasiswa yang berjumlah 27 tersebut, skor yang diperoleh mahasiswa pada hasil Tes Awal terdapat 20 mahasiswa $(74,1 \%)$ berada pada TK Kurang, pada Siklus I terdapat 5 mahasiswa $(18,6 \%)$, pada Siklus II dan Siklus III tidak ada mahasiswa yang memperoleh skor bertingkat kemampuan Kurang. Skor TK Sedang, hasil Tes Awal terdapat 7 mahasiswa $(25,9 \%)$, pada Tes Akhir Siklus I terdapat 22 mahasiswa $(81,4 \%)$, pada Tes Akhir Siklus II terdapat 26 mahasiswa (96,3\%), dan setelah Siklus III menjadi 15 mahasiswa (56\%). Skor Tes Awal dan Tes Siklus I tidak ada mahasiswa (0\%) yang memiliki TK Tinggi, pada Tes Akhir Siklus II terdapat 1 mahasiswa ( $0 \%)$, dan pada hasil Tes Akhir Siklus III terdapat 12 mahasiswa (44\%) berada pada TK Tinggi.

Kemampuan kelas dalam memaparkan unsur CA dari Tes Awal sampai Tes Akhir Siklus III semakin meningkat. Dari mahasiswa yang berjumlah 27 tersebut, pada hasil Tes Awal terdapat (68\%) berada pada TK Kurang, pada Siklus I terdapat $(45,9 \%)$, pada Siklus II terdapat $(11,1 \%)$, 
dan pada Siklus III (0\%). Pada TK Sedang, hasil Tes Awal terdapat (31,7\%), pada Tes Akhir Siklus I terdapat (53,3\%), pada Tes Akhir Siklus II terdapat (79\%), dan setelah Siklus III kemampuan kelas dalam memaparkan unsur CA menjadi (43\%). Untuk TK Tinggi, pada hasil Tes Awal terdapat $(0,3 \%)$, Tes Akhir Siklus I terdapat (0,9\%), Tes Akhir Siklus II terdapat (9,9\%), dan Tes Akhir Siklus III kemampuan kelas dalam memaparkan unsur CA terdapat (57\%).

Berdasarkan simpulan di atas, disampaikan saran-saran sebagai berikut. Pertama, Dosen Bahasa Indonesia PGSD dalam meningkatkan kemampuan mahasiswa dalam pembelajaran menulis, khususnya dalam penulisan CA disarankan menggunakan Strategi Menulis Terbimbing. Kedua, sistem pemberian tugas dan penilaian dalam pembelajaran bahasa Indonesia, khususnya menulis CA melalui SMT hendaknya menggunakan berbagai cara dalam prosesnya. Ketiga, penataan kelas perlu disesuaikan dengan tugas yang harus dikerjakan mahasiswa. Keempat, mahasiswa PGSD sebagai calon guru SD yang telah memiliki pengetahuan dan pemahaman tentang cara menulis $\mathrm{CA}$, apa yang akan ditulis, dan bagaimana caranya menulis, disarankan berani mencoba menulis cerita untuk anak SD. Kelima, pengelola PGSD sebagai lembaga yang menyiapkan guru SD, hendaknya memberi kesempatan kepada dosen mata kuliah Bahasa Indonesia untuk memberikan pelatihan kepada guru-guru SD serta mahasiswa PGSD tentang penulisan CA. Keenam, hasil penelitian menunjukkan bahwa SMT memiliki nilai positif dalam strategi pembelajaran menulis CA khususnya bagi dosen. Untuk itu, disarankan kepada peneliti berikutnya agar meneliti dengan menggunakan SMT baik di sekolah maupun di kampus.

\section{UCAPAN TERIMA KASIH}

Ucapan terima kasih kepada kedua promotor penulis Prof. Dr. Sabarti Akha- diah dan Prof. Dr. Njaju Jenny M.T. Hardjatno, yang telah membimbing penulis hingga disertasi ini selesai dan penulis dinyatakan lulus, Ketua Jurusan dan Sekretaris Jurusan Pendidikan Bahasa UNJ, dan Ketua Jurusan dan Sekretaris Jurusan Prodi PGSD yang telah banyak membantu penulis untuk kelancaran studi ini. Dosen Mata kuliah Bahasa Indonesia dan mahasiswa PGSD yang telah bersedia untuk dijadikan subjek penelitian, dan Siswa-siswa SDNP 1 Yogyakarta, SD Gedongkiwo Yogyakarta, dan SD Sampangan Bantul yang telah bersedia membaca CA karya mahasiswa. Ucapan terima kasih juga disampaikan kepada Dewan Redaksi Jurnal Litera, terutama kepada ketua dan sekretaris yang telah bersedia mereviu tulisan ini menjadi lebih baik. Semoga Allah Yang Maha Kuasa melimpahkan Taufik dan HidayahNya kepada semua yang telah menjembatani penulis hingga tulisan ini terbit di Jurnal Litera FBS UNY.

\section{DAFTAR PUSTAKA}

Ausubel, David P., Joseph D. Novak, dan Hele H. 1978. Educational Psychology. New York: Holt, Rinehard and Winston.

Bodrova, E. dan Deborah J.L. 1996.Tool of the Mind, The Vygotskian Approach to Early Childhood Education. Columbus: Merill an imprint of Prentice Hall.

Brek, L.E dan Adam W. 1995. Scaffolding Childrens Learning, Vigotsky and Early Childhood Education. Washington, DC: NAEYC Research Info Practice Series.

Cooper, C.R. \& Lee O. 1977. Evaluating Writing Describing, Measuring, and Judging. New York: State University of New York at Buffalo.

Dworetzky, J.P. 1990. Introduction to Child Development, New York: West, Publishing Company.

Gunning, G.T. 1992. Creating Reading Instruction for All Children. Boston: Allyn and Bacon. 
Kemmis, S. dan R. Mc. Taggart. 1988. The Action Research Planner. Victoria: Deakin Univercity.

Miles, M.B., dan A. Michel Huberman. 1984. Qualitative Data Analysis: A Sourcebook of New Methods. London: Sage Publications.

Mills, G.E. 2003. Action Research: A Guide for the Teacher Researcher. New Jersey: Merrill Prentice Hall.

Moore, D.W., Sharon M., Patricia M; Cunningham; James W. Cunningham, 1996. Developing Readers and Writers in the Content Area. New York: Longman.
Saxby, M. dan Gordon W. (ed). 1991. Give Them Wings, The Exsperience of Children's Literature. Melbaurne: The Macmillan Company.

Spodek, B. dan Olivia N.S. 1994. Right from the Start: Teaching Children Ages Three to Eight. London: Allyn and Bacon.

Tompkins, G.E. 1994. Teaching Writing: Balancing Process and Product. Macmillan: Collage Publishing Company, Inc.

Tompkins, G.E. dan Kenneth H. 1995. Language Arts. Content and Teaching Strategies. New Jersey: Prentice Hall, Inc. 